\title{
Recent Monetary Actions
}

(a) INCE LATE 1967 the Federal Reserve System has moved in the direction of a less expansionary monetary policy. The Federal Reserve Banks raised their discount rates from 4 per cent to $4^{1 / 2}$ per cent in late November. At the December 12 meeting of the Federal Open Market Committee a decision was reached to move toward a modestly tighter open market policy, At this meeting the trading desk at the New York Federal Reserve Bank was given the directive that "System open market operations until the next meeting of the Committee shall be conducted with a view to moving slightly beyond the firmer conditions that have developed in the money market." However, a proviso clause was added "that operations shall be modified as needed to moderate any apparently significant deviation of bank credit from current expectations or any unusual liquidity pressures."

In mid-January of this year reserve requirements on member bank demand deposits in excess of $\$ 5$ million were increased from $161 / 2$ to 17 per cent for reserve city banks and from 12 to $12 \frac{1}{2}$ per cent for other member banks. In mid-March, in response to developments in the international monetary area and in an effort to bring the discount rate more nearly in line with prevailing market interest rates, the Federal Reserve Banks raised their discount rates from $4 \frac{1}{2}$ to 5 per cent. On April 18 a further increase in the discount rate was announced, this time to $5^{1 / 2}$ per cent, the highest level since October 31, 1929.

\section{Indications of Monetary Restraint}

Although the recent month-to-month movements in the major monetary aggregates, such as money and bank credit, have been somewhat erratic, it appears that since last November most of the monetary aggregates have grown at slower rates than during the previous ten months.

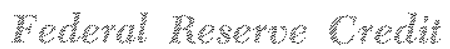

Federal Reserve credit outstanding has grown at a 13 per cent annual rate since November, compared to a 12.2 per cent rate during the January-November period of 1967. Federal Reserve credit is composed of two major items, Federal Reserve holdings of Government securities and member bank borrowings at Fed- eral Reserve Banks. Over the last three months of 1967 the System's holdings of Government securities averaged $\$ 48.5$ billion. In the first four months of 1968 holdings have averaged $\$ 49.3$ billion, $\$ 49.2$ billion, $\$ 49.8$ billion, and an estimated $\$ 50.5$ billion, respectively. The increase in Federal Reserve holdings of Government securities partly reflected System actions offsetting the impact on member bank reserves of the recent heavy outllow of gold. The gold stock declined from an average of $\$ 12.4$ billion in December to about $\$ 10.5$ billion at the end of March.

The most rapidly increasing component of Federal Reserve credit since December has been member bank borrowings from Reserve Banks. Two major sources of borrowing available to member banks to meet their short-term cash needs are borrowings from the Federal Reserve Banks, and borrowings from other commercial banks in the Federal funds market.

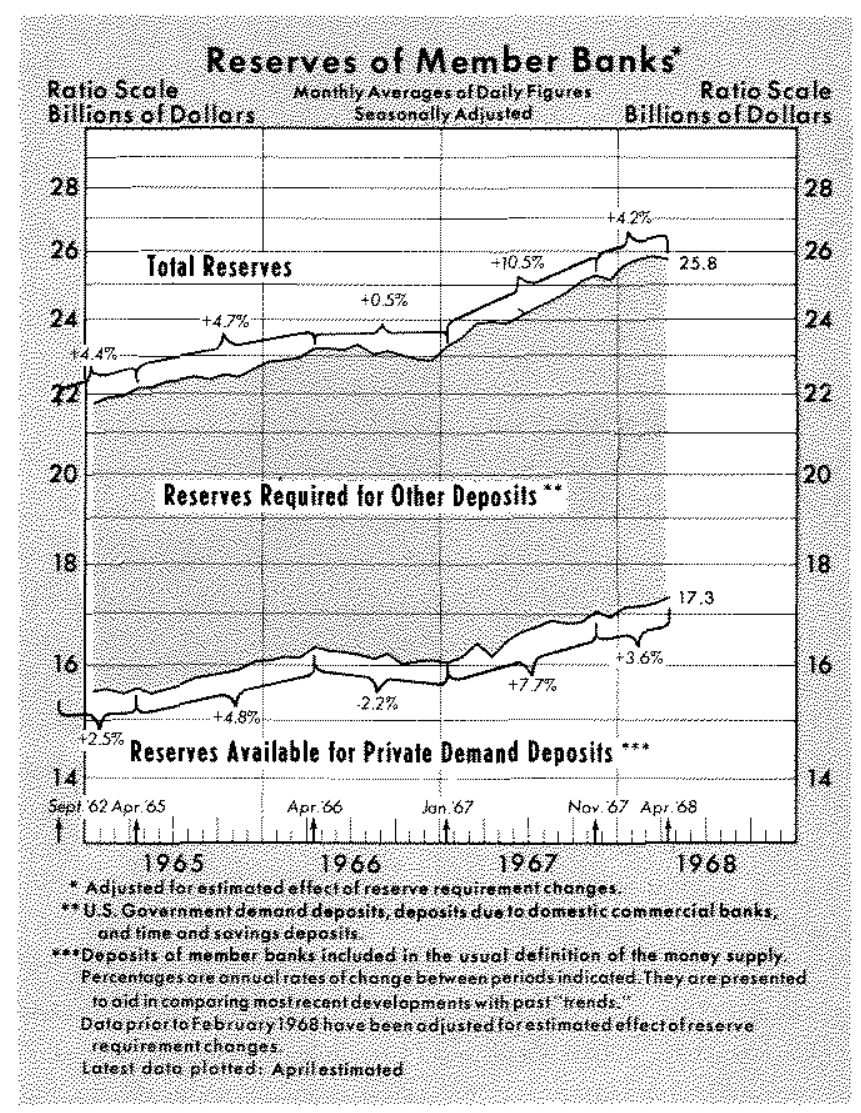


In mid-December the rate on Federal funds moved above the $4 \frac{1 / 2}{2}$ per cent discount rate. As a consequence, borrowings at Federal Reserve Banks became a much more attractive source of short-term funds for the member banks.

Federal funds, which had traded in the 4 to $4 \frac{1 / 2}{2}$ per cent range during most of December, traded at an average of 4.72 per cent during February, and then rose to an average of 4.79 per cent during the first two weeks in March. Around mid-March the Federal Reserve Banks raised their discount rates to 5 per cent. However, the rate on Federal funds quickly moved above the 5 per cent level, averaging 5.28 per cent in the last half of March. In early April the rate on Federal funds continued to rise, averaging 5.69 per cent over the first eighteen days. From April 19, when the discount rate was increased to $5 / 2$ per cent, to April 30 Federal funds traded at an average of 5.81 per cent. Member bank borrowings from Federal Reserve Banks, which averaged \$166 million over the last three months of 1967, in the first four months of 1968 averaged $\$ 237$ million, $\$ 361$ million, $\$ 671$ milm lion, and about $\$ 690$ million, respectively.

\section{Towal Reserves}

The rate of increase in Federal Reserve credit since November has permitted an estimated 4 per cent rate of increase in total reserves of member banks over the period. This rate of growth is considerably below the rapid rate of 10.5 per cent experienced in the January to November period of 1967 , and is about the same as the trend rate of 3 per cent over the period 1957 1966, but well above the average rate of 2.7 per cent over the $1957-1966$ period. The increase in total reserves during February and March was used primarily to support a major increase in U.S. Government demand deposits at member banks. From January to March government demand deposits rose at a 217 per cent annual rate.

Reserves available for private checking accounts (total reserves less reserves required for government, time, and net interbank deposits) rose at an estimated 3.6 per cent annual rate from November to April. By comparison, these reserves increased at a 1.5 per cent rate from 1957 to 1966 , and then grew at an accelerated 7.7 per cent annual rate from January to November of 1967 .

\section{Monen and Bank Credit}

Reserves of member banks, which include member bank deposits at Federal Reserve Banks and vault cash, provide the base for the money supply and bank credit. Since November the money stock has grown at an estimated 5 per cent annual rate. The rate of increase in money represents a slowing from the growth rate of 7.7 per cent occurring over the previous ten months. However, this growth rate of money is considerably above the average annual rate of 2.4 per cent experienced over the nine-year period from 1957 to 1966.

Over the January to November period of 1967 total bank credit grew at a rapid 12 per cent annual rate. From last November to April of this year bank credit grew at an estimated 6 per cent rate, about the same as the average growth rate of 7 per cent occurring over the period 1957-1966. Since November, while bank loans have grown at about the same rate as over the first ten months of 1967 , banks' holdings of securities have grown at a sharply reduced rate compared to the previous ten months. From November to April bank investments grew at an estimated 4.3 per cent annual rate and bank loans rose at an estimated 7 per cent annual rate, compared to growth rates of 22 per cent and 7.3 per cent, respectively, over the previous ten months. The more rapid growth of the loan component of total bank credit relative to the investment component, marks a return to the relation between the longer term growth rates of these two components. Over the 1957-1966 period the investment component of total bank credit rose at an average annual rate of 3.3 per cent, and the loan component grew at a 9.3 per cent rate.

\section{The Doposits}

The broader aggregate, the money supply defined to include time deposits, has likewise shown a slower growth trend in recent months. Since November this

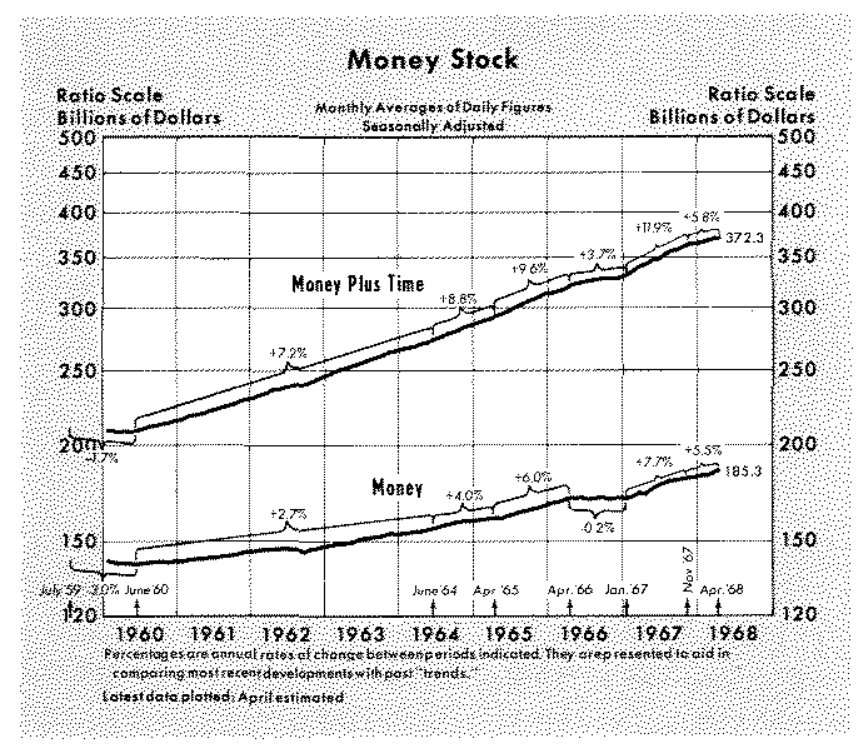


broader concept of money has grown at an estimated annual rate of 5.5 per cent, considerably below the rate of 12 per cent occurring in the previous ten months.

This slower rate of growth of money plus time deposits reflected primarily the slower growth rate of the time deposit component. Time deposits rose at an estimated 6 per cent annual rate in the period from November through the first four months of 1968 , compared with a 16 per cent annual rate over the January to November period of 1967 , and a trend rate of 12 per cent over the longer period 1957-1966.

The slower growth rate of time deposits has been especially evident in the slower growth of negotiable time certificates of deposit in denominations of $\$ 100,000$ or more. Commercial banks are restricted by Regulation $Q$ on the maximum rates they can pay on different classes of time deposits. Since available yields on competitive market assets have risen relative to these fixed ceiling rates, the slower growth of time deposits may reflect the increased attractiveness of other financial assets. Until April 19 commercial banks could pay a maximum rate of $5 \frac{1}{2}$ per cent on these certificates. In mid-March the market rates on outstanding large CDs trading in the secondary market moved above the $5^{1 / 2}$ per cent ceiling rate payable on newly issued CDs. With outstanding large CDs selling at a discount, commercial banks had an increasingly difficult time in attracting and holding these types of funds. From mid-March to mid-April the amount of certificates of deposit in denominations of $\$ 100,000$ or more issued by large commercial banks decreased by $\$ 1.5$ billion. Effective April 19 , the ceiling rates on large denomination $\mathrm{CDs}$ were raised by the Board of Governors. The maximum rate payable on large CDs, which was previously $5 \frac{12}{2}$ per cent on all maturities of 30 days or more, was changed to:

$\begin{array}{cc}\text { Maturity } & \begin{array}{c}\text { Maximum rate } \\ \text { in per cent }\end{array} \\ 30-59 \text { days } & 5^{1 / 2} \\ 60-89 \text { days } & 5^{3 / 4} \\ 90-179 \text { days } & 6 \\ 180 \text { days and over } & 6^{1 / 4}\end{array}$

\section{Total Spending and Prices}

Inflationary pressures still remain prominent in the economy. From the last quarter of 1967 to the first quarter of 1968, real GNP rose at an annual rate of 6 per cent and the implicit price indicator increased at a 4 per cent rate.

From the fourth quarter of 1967 to the first quarter of this year, total spending on goods and services rose at an estimated 10.3 per cent annual rate. In comparison, total spending increased 6 per cent during 1967. Consumer spending accelerated in the first quarter to a 13 per cent annual rate, with purchases of durable goods up at a 24 per cent rate. In comparison, consumer spending increased by 6 per cent during 1967.

Business spending for capital expansion and Govermment spending for goods and services both increased at rapid rates in the first quarter of this year Business capital expenditures for structures and durable equipment rose at a 16 per cent annual rate in the first quarter, compared to an increase of 1.4 per cent from the fourth quarter of 1966 to the fourth quarter of 1967. Government spending rose at a 13 per cent annual rate, compared to an increase of 12 per cent during 1967.

Industrial production in the first quarter was up at an annual rate of 5.4 per cent from the previous quarter, and nonfarm payroll employment rose 5 per cent during the period. These rates of increase reflect a continuation of the upturn in industrial production and employment which began last summer. Despite the rise in industrial production and payroll employ. ment, demands for goods and services rose more rapidly. Reflecting these demand pressures on the productive capacity of the economy, prices continued to rise sharply. From December to March the consumer price index rose at a 4.5 per cent annual rate, and the wholesale price index of industrial commodities rose at the same rapid rate.

In the first quarter substantial gains were recorded in personal income, reflecting a rise in employment, a higher minimum wage, and wide-spread gains in

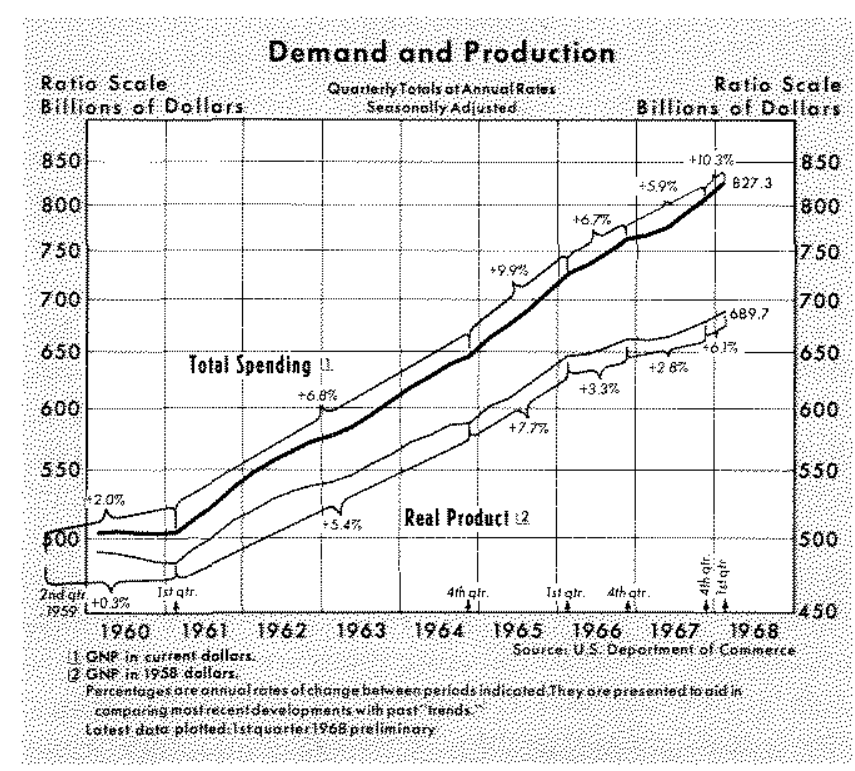


wage rates and salaries. Wages and salaries rose at an estimated annual rate of 11 per cent during the first quarter of 1968.

In the first quarter an estimated 30 million persons received an increase in income as a result of new Government laws. An increase of at least 13 per cent in Social Security payments became effective with the monthly payments made by the Government in March. In February approximately 6 million individuals received pay increases as the result of an increase in the minimum wage rate from $\$ 1.40$ to $\$ 1.60$ an hour, and an additional one million individuals received an increase in wages to $\$ 1.15$ an hour.

\section{Has Monetary Policy Tightened Enough?}

Monetary policy is only one of the two major sets of actions that may be taken by policymakers to encourage or restrict the growth rates of total spending, output, employment, and prices in the economy. The other important set of policy actions is broadly labeled fiscal policy and includes Government spending and tax policies. These two sets of actions are not mutually exclusive. A change in the operations of the fiscal authorities has an effect on the environment in which monetary policy actions are implemented.

Later last year, in the face of rising inflationary pressures, monetary policymakers adopted a more restrictive policy. This move toward less monetary ease has shown up, since last November, in some slowing of the growth rates of the major monetary aggregates compared to their respective growth rates over most of 1967. During the first four months of 1968, as shown by the continued rapid rise of total spending, especially by the Government sector and the apparent resurgence of consumer demand, it appears that inflationary pressures are still present and increasing in 1968.

Few economists claim that the impact of a given set of monetary policy actions has an immediate effect on the amount of total spending and prices. Intuitively, one would expect that it takes time for individuals and firms in the economy to adjust to changes in existing monetary conditions, and empirical studies lend support to these beliefs. Nevertheless, the end goal of monetary policy actions should be to affect total spending, output, employment, and prices. When attempting to assess whether their policy measures are appropriate, monetary policymakers should ultimately base their assessment on the observed growth rates of these real variables. However, information on these developments are available only after a time lag, and the impact of monetary actions affects the real variables only after another time period. As a result, more proximate indicators of monetary actions are used to judge actions in relatively short time periods.

Growth rates in money have been used frequently as a proximate measure of the effect of monetary actions on the economy. Last year money rose at a rapid 7 per cent rate, and the economy developed excesses. Since last November the growth rate in money has slowed to a 5 per cent rate. To the extent that the growth rate of money is a good measure of the effect of monetary actions on the economy, some lessening of the excesses should occur. But in view of an average trend rate of growth in money of 2.4 per cent over the nine-year period 1957-1966, it may be that monetary actions remain unduly expansive. By use of other monetary aggregates as a guide to policy actions, such as bank credit, or measures of money market conditions, such as interest rates, somewhat different conclusions might result.

A set of policy actions aimed at maintaining one constellation of money market conditions and a set of growth rates of certain monetary aggregates such as bank reserves, money, and bank credit may, under one set of conditions existing in the economy, have the effect desired by policymakers on total spending, output, employment, and prices. Under a different set of conditions, these same policies may not have their desired effects. As a hypothetical example, policies aimed at maintaining the present set of money market conditions and attempting to restrict the growth rate of money to a 3 to 6 per cent rate, and the growth rate of bank credit to a 6 to 8 per cent rate may, under conditions of a 10 per cent income surtax, have the desired effect of restraining the growth of total spending and prices. In the absence of such a tax increase and/or with the resurgence of the rate of consumer spending, a monetary policy may be required that is directed toward maintaining a different set of money market conditions and slower growth rates of the monetary aggregates.

Different sets of underlying structural relations in the economy may require different monetary policy actions. The two statements, "Compared to past experience, short-term interest rates are at very high levels" and "The recent growth rates of money and/or bank credit are both slower than over the previous ten months," by themselves, or taken together, may imply the conclusion that monetary policy is having the desired effect of reducing the growth rates of total spending and prices. However, either statement, taken by itself, or the two statements taken together, does not necessarily imply that monetary policy is having the desired effect of reducing the growth rates of total spending and prices. 